\title{
Presence and Use of Pragmatic Legal Literature in Habsburg Peru (16th-17th Centuries)
}

\author{
Renzo Honores
}

Around 1642, the priest and chronicler Fernando de Montesinos (d. 1652) wrote regretfully how the Curia Philipica had been widely used by mestizos and Andeans in litigation. ${ }^{1}$ For the author of Anales, the consultation and social usage of this procedural manual had rocketed the lawsuits in the Limeño Audiencia. His pessimistic view on how "subaltern" groups had mischievously used prácticas was a common perspective among other Habsburg colonial authors. Thus, in 1561, the notable jurist Licentiate Polo Ondegardo (1517/1520-1575) condemned acrimoniously how the Andean subjects had appropriated the Castilian law. ${ }^{2}$ This phenomenon, he argued, had perverted the sense of justice especially among the natives. As an example, he cited endless opportunities in which Cuzqueño people offered their testimonies for economic returns. His experience as magistrate in the former Inca capital convinced him to propose judicial reforms. Polo's view was not an isolated one. In 1588, Father Bartolomé Alvarez, also in Cuzco, accused the Andean ladinos of using irresponsible litigation manuals like Gabriel de Monterroso's Practica civil y criminal (of 1563) for

1 His words were eloquent: "[Hevia Bolaños' Curia Philipica] a hecho mucho daño en este Reyno, no por mala, sino por bien entendida: todos son letrados; especialmente los mestizos se inclinan a esto [litigation in courts], ya me dicen que los indios también tratan de esto y andan en sus pueblos amenaçando a los corregidores y curas con la Curia", in Montesinos, Anales del Perú, vol. 2, 222. I thank Herman Barreto for this and other references.

2 Polo Ondegardo was the first Spanish jurist who proposed the recognition of customary law as a means to reduce indigenous litigation in the Andes. He presented the hyper-litigation as the consequence of professional manipulation (by lawyers), cultural misunderstanding, and perversion of the justice's goals. He stated: "que cierto ésta es cosa de lástima verlos enseñados a nuestras trampas, hecho pleitistas por las audiencias, y lo que peor es, que entendida la fuerza de nuestra justicia consistir la mayor parte en testigos, hallando fácil el remedio por la gran facilidad de los indios, ya no piden lo que cada uno cree ser suyo o pertenecerle, sino lo que había menester o le viene a propósito [...] y hase hallado plaza pública de viejos que venían de sus tierras a ganar de comer por testigos, y se sentaban a hora cierta para ser alquilados", in Ondegardo, Informe del licenciado Polo Ondegardo, ed. Lamana, 144.

(C) RENZO HONORES, 2020 | DOI:10.1163/9789004425736_005

This is an open access chapter distributed under the terms of the CC-BY-NC 4.o licepse.zo Honores - 9789004425736 
their disputes. ${ }^{3}$ In the early 17 th century, the authors of manuals highlighted the importance of their production for improving and reforming the practice of law. Jurists, priests, and theologians coincided in the opinion that the legal literature should be used to reform the role of experts as guarantors of justice. ${ }^{4}$ That period marks the rise of the idea of professionalisation in legal practice but also the dissemination of legal concepts through printed pragmatic production. ${ }^{5}$ Legal literature was crucial in the effort for regulating the practice, providing templates for laymen, and guiding the conduct of facilitators.

This preliminary essay explores the circulation of 'pragmatic books' and their juridical categories in the Habsburg Andes. 'Pragmatic' literature refers to legal and moral literature written in vernacular language, a corpus that oriented the professional and local practice producing normative effects. ${ }^{6}$ This universe of intellectual production was intended for its daily usage in justice administration, local government, and the spiritual legal/moral order. This corpus generated normative effects on the King's subjects because it regulated their own lives, rights, and patrimonies. ${ }^{7}$ In late medieval and early modern Castile, the manuals were called prácticas to distinguish them from the legal treatises (tractatus in Latin), a more sophisticated body of doctrinal ideas in law. ${ }^{8}$ However, pragmatic literature itself incorporated legal categories and helped to disseminate them to a broader audience. While prácticas circulated in local spheres, they were also used in seats of Audiencias, the great centres of legal production. This chapter argues that pragmatic legal literature became

3 The Práctica had at least eight editions between 1566 and 16og. In 1591, this manual was on sale in Lima's bookstores, see Ondegardo, Informe del licenciado Polo Ondegardo, ed. Lamana, 524. Palau y Ducet indicates a first edition dated in 1563 (Palau y Ducet, Manual del librero hispanoamericano, vol. 10, 122). On Father Alvarez's words, see his report to Philip II (Alvarez, De las costumbres y conversión de los indios del Perú, 268-269), a discussion on this point, in Danwerth, "La circulación de literatura normativa pragmática en Hispanoamérica", 389.

4 Priest Bartolomé Vadillo (1593-1659) postulated a moral model for the advocacy and magistracy in colonial Lima, see his sermon of 1648.

5 By professionalisation, this essay refers to a group of specialists who monopolised (or tried to do so) the legal services in return for economic compensations. In the case of litigation, the experts were the abogado (advocate) and the procurador de causas (procurator). In colonial Peru, they appeared and proliferated in several cities around the mid-16th century.

6 Danwerth, "La circulación de literatura normativa pragmática en Hispanoamérica".

7 I am indebted to Otto Danwerth for this definition and for providing information on this valuable contribution and its current relevance for studies in legal history. Roderich von Stintzing (1825-1883), lawyer and legal historian, explored the popular legal literature in the late medieval and early modern Holy Roman Empire. The result of his research was his book Geschichte der populären Literatur des römisch-kanonischen Rechts in Deutschland, Leipzig 1867.

8 Alonso Romero, "Theoria y Praxis en la enseñanza del Derecho". 
part of the legal universe in the Peruvian viceroyalty and was used by legal facilitators and laymen.

By focusing on the first two centuries of Spanish colonialism, this chapter emphasises the significance of that period in the making of a colonial legal culture. The term 'legal culture' refers to the knowledge and social usage of law. The rule of the Habsburg dynasty is considered as an example of pluralism and legal diversity in Europe and the Americas. ${ }^{9}$ The Habsburgs were also the leaders of the Counter-Reformation and the crafters of the enduring Spanish "Catholic monarchy". Due to the dimensions of its vast dominions, the production of Italian and Flemish printing presses circulated in the New World. This essay examines the functions of that pragmatic juridical literature in the practice of law. This intellectual production exerted a capital influence on the justice administration, the arguments of professionals and ordinary citizens, and on the construction of a rhetoric of justice and good government. Such a political and legal lexicon was a cornerstone in the design of the Habsburg juridical framework. Legal rhetoric was constructed by various agents, and legal literature epitomised in prácticas played a significant role in its making.

This exploratory contribution has been divided into three parts. Part one examines pragmatic legal literature and its consumption in Habsburg Peru. The second part pays attention to the use of these laws and rhetoric in higher and lower courts. Finally, part three analyses the genesis of a legal culture in the colonial Andes, a historic process in which both professionals and litigants participated.

The Presence of Pragmatic Literature and the Local Book Market

Since the mid-16th century, a population of consumers of legal publications existed in the Andes. Practitioners settled gradually across several cities. In Lima, for instance, the class of lawyers, procurators, and scribes were already visible in $1538 .{ }^{10}$ Other places like Cuzco (in the south) and Trujillo (in the north) held a community of specialists for litigation in the decade of the 1550 . Between the 156 os and 1570s, a growing population of legal experts installed in La Plata

9 Härter, "The Early Modern Holy Roman Empire of the German Nation", 113-122.

10 Libros de cabildos de Lima. Libro primero, ed. Lee, 234-235. The two first agents for litigation, procurators, were Alonso de Navarrete and Pedro de Avendaño. The latter developed an impressive career becoming the private secretary of Viceroy Marquis of Cañete (r. 1556-156o) and of the Audiencia of Lima. Pedro de Avendaño was the head of an influential lineage in the city. 
(today's Sucre) and later in Potosí. At least in a period of forty years after the conquest, the main centres of Spanish urban presence had a numerous class of professionals. In the early 17th century, the Villa Imperial of Potosí, the largest and most populous Andean metropolis, had such a number of practitioners that it surpassed other cities in this regard. ${ }^{11}$

Notarial records demonstrate the existence of an early book trade for forensic purposes in the mid-16th century. At that time, the production was entirely imported to the new viceroyalty, which benefited from the "boom" of publications in Spain, Spanish Italy and Flanders. ${ }^{12}$ Manuals like Gabriel de Monterroso, Práctica civil and criminal, ecclesiastical handbooks, treatises and legislation were sold in Limeño bookstores. ${ }^{13}$ At the end of the century, booksellers were very active in the city and had a fruitful commercial connection with their Sevillian counterparts. ${ }^{14}$ Notarial documents show how the market was growing and the literary legal production was manifold, including practical juridical authors. The population of consumers were not exclusively Europeans or settlers. Demographic changes in the viceroyalty caused the rise of a new population of Creoles, who began to be educated in law since $1575 .{ }^{15} \mathrm{In}$ just a couple of years, they turned into the majority of Limeño legal facilitators. The 17th century was the time of the apogee of Creolism, and it was clearly visible with regard to political and intellectual actors as well. A significant number of descendants of conquerors became lawyers and played an important role as crafters of legal arguments in courtrooms. They wrote the claims, counterclaims, and pleas in the trials. Some of their libraries illustrate the presence of pragmatic literature. According to the book inventory of Doctor Cipriano de Medina's collection, documented in 1635, he possessed the Practica Papiensis

11 [Anon.,] Descripción de la Villa y minas de Potosí.

12 In the period of $1500-1520,40 \%$ of the peninsular book production was religious, and the law works reached $11 \%$. The percentages changed little at the end of the century. In the years of 1580-1600: $46 \%$ were religious works and $16 \%$ books on jurisprudence (or law), see Wilkinson, "Ensayo introductorio. La publicación en la Península Ibérica a principios del Siglo de Oro", XXXVIII and XL.

13 Some of the jurists whose books circulated in mid-16th century Lima were Cino da Pistoia (c. 1270-1336/1337), Baldo degli Ubaldi (1327-1400); legislative publications included Las Siete Partidas (1256-1265), Ordenamiento Real (or Montalvo, 1484), and Leyes de Toro (1505).

14 Leonard, "On the Lima Book Trade, 1591".

15 The first courses of the Faculty of "Leyes y Cánones" was established in 1571 and the curriculum was completed in 1578. The reforms were initiated by viceroy Toledo in a process of secularisation and transformation of the Colegio del Rosario in the decade of the 157 os, see Monsalve, "Del estudio del Rosario a la Real y Pontificia Universidad Mayor de San Marcos", 68-73. 
(of Venice in 1549), Instrucción política y práctica judicial (of Villadiego in 1612), and Practica de exsaminar testigos, among other books. ${ }^{16}$

Likewise, an influential group of native chiefs were literate, bilingual, and educated in colleges (especially in Lima and Cuzco). ${ }^{17}$ Some of them, like don Rodrigo de Guzmán Rupaychagua, had been educated in the Jesuit College for caciques in Lima in the $17^{\text {th }}$ century. ${ }^{18}$ After his formal education, he became a prominent litigant in civil and canonical tribunals, and a skilful user of legal channels. ${ }^{19} \mathrm{He}$ was part of a long generation of Andean litigators who date back to the mid-16th century, the time of the legal boom in the Real Audiencia of Lima. The 17th century was the time of a more formal group of trained indigenous scribes and provincial professionals. ${ }^{20}$ They were consumers of legal production despite the fact that we only dispose of wills from the 18th century. One important example of a conspicuous leader and legal user was the cacique don Cristóbal Choquecasa, an Andean lord in Huarochirí, located in central Peru, close to Lima. The history of litigating caciques with a skilful command of legal terminology dates back to the early mid-16th century. The first testimonies of these lords show their ability and familiarity in the use of legal institutions.

Whereas the early book trade was dominated by the import of European production, in 1584 a printing press was established in Lima. The printer Antonio Ricardo, an Italian with a long editorial experience in Europe and Mexico, relocated to the viceregal capital. The early local printed production was pastoral. The Third Provincial Council of Lima (1582-1583), the great Church assembly of that century, was the decisive agent for this editorial endeavour.

16 Novoa, The Protectors of Indians in the Royal Audiencia of Lima, 255.

17 On the education of Andean nobility and the libraries in the cacical colleges, see Alaparrine-Bouyer, "La biblioteca del Colegio de Yngas nobles" and Alaparrine-Bouyer, $L a$ educación de las élites indígenas en el Perú colonial. Caciques studied Christian doctrine, Spanish, and Latin. Although the "spiritual" education was central in the formation of the young native chiefs, they became familiar in the use and consultation of legal books. Rupaychagua, cacique of Huamatanga, in Canta (in Lima's highlands), is one of the representative examples; see Charles, “'More Ladino than Necessary'”.

18 Alaparrine-Bouyer, La educación de las élites indígenas en el Perú colonial.

19 There were prominent examples of litigating caciques in the 16th century: don Diego de Ataurimache, don Felipe Guagrapaucar (cacique in Jauja and traveler to the court of Madrid in 1563). Don Francisco de Mayontopa (member of the Inca elite and cacique in Ollantaytambo), among other prestigious lords. The best study of Andean litigation and the role of lords is Puente Luna, Los curacas hechiceros, 227-273. For transatlantic Andean litigation and the making of an early modern legal culture, see Puente Luna, Andean Cosmopolitans, 51-88.

Ramos, "Indigenous Intellectuals in Andean Colonial Cities", 26-35. 
Confessional manuals, guidelines for evangelisation, and the decisions of the Council were produced in the Ricardian workshop. This pattern of canonical topics was dominant in the rest of the century. Confession manuals were printed for the evangelisation, and contributed to forge a normative order in the Andean parishes. In the High Middle Ages, confession was a central instrument for disciplining the Christian believers. Pope Innocent III (r. 1198-1216) led the assertion of papal authority in Europe promoting the mandatory character of the seven sacraments. The papal revolution aimed at controlling the subjectivity and behaviour of peasants and ordinary citizens. ${ }^{21}$ This European experience was replicated in the New World. In the Andes, penitential works and definitions of sins (translated from Spanish to Quechua) were the means for the dissemination of the Christian notions (and values) of sex, family, commerce, and labour. ${ }^{22} \mathrm{~A}$ spiritual legal order that regulated the life and goods of believers emerged from that process.

In the $17^{\text {th }}$ century, a young generation of Peruvian priests (some of them members of the aristocratic elite) penned sermons. They cultivated the art of the sacred oratory as another vehicle for moralising the society. ${ }^{23}$ One of the most prolific was Bartolomé Vadillo (1593-1659), an Augustinian friar, considered by his contemporaries as the pico de oro (the great rhetorician) of theological thought in mid-17th century Lima. His sermons dealt with everyday life aspects of the city: ethics, legal practice, justice administration, law and order. He supported his reflections by using passages taken from the sacred scripture and Scholastic authors (Thomas Aquinas, for instance). Thus, rather than 'abstract' and vague definitions, Vadillo discussed urgent social problems and employed concrete examples to explain his theological views. ${ }^{24} \mathrm{He}$ was not the only one of several authors who examined and discussed moral topics. Vadillo was also an author of a manual for testaments, written under the premise of popularising the ways to declare the last will. This production was printed and circulated in Lima. The work on testaments was oriented to the laymen.

21 On canon law and its incidence on private life, see Brundage, Medieval Canon Law, 70-97.

22 Harrison, Sin and Confession in Colonial Peru, 84-219.

23 Theologians and theology professors were usually asked by the authorities to yield their opinions on indigenous labour in mining. Friar Miguel de Agia, lecturer in theology, wrote his Tratado que contiene tres pareceres graves en Derecho to examine the mita sytem in Huancavelica, the main producer of mercury. Another important Franciscan, Pedro Muñiz, also lecturer in theology, was the author of a report on indigenous working conditions in mining centres, see Fox, "Pedro Muñiz, Dean of Lima and the Indian Labor Question".

Vadillo, Sermón en el quarto miércoles de quaresma. 
That century was the epoch of a significant local writing in the Peruvian viceroyalty. Guillermo Lohmann Villena and Ella Dunbar Temple have called this momentum the "Golden Age" of intellectual history in colonial Peru. ${ }^{25}$ The massive circulation of books, the constitution of impressive conventual and personal libraries, and the intellectual energy of local lawyers, practitioners, and priests contributed to this rise. ${ }^{26}$ An Asturian author, Juan de Hevia Bolaños, who worked as legal representative of litigants in the Audiencia, wrote his influential Curia Philipica, a manual for litigation in both civil and criminal jurisdictions. Although his handbook was intended as a guide to illustrate the stages of a procedure, in a short time it became a best seller with numerous editions in Lima and the Peninsula. Hevia's work opened up the period of manuals that inundated the Limeño presses. In 1640, Domingo Gómez de Silva, judge of minors, published his Práctica e instrucción para albaceas, tutores y curadores, with important guidelines for the judicial administration of the minors' patrimony. ${ }^{27}$ Litigation on mismanagement of these assets was a common feature in the Audiencia of Lima during the Habsburg era. Manuals for scribes were also part of the repertory of this local production. ${ }^{28}$

Advocates also printed their legal allegations. In the 16th and 17 th centuries Limeño litigation, legal pleadings were written by hand being inserted into the trial proceedings. In the nascent epoch of Philip III (r. 1598-1621), Limeño lawyers (sponsored by their clients) printed out their claims, albeit they were ultimately not included in the proceedings. In these pieces, they pointed out their clientele's rights elaborating long and detailed juridical justifications. ${ }^{29}$ In Madrid and Mexico City, the printing of this production was common and prior

25 "El jurista indiano don Gaspar de Escalona y Agüero", 570.

26 On conventual book collections, see the study by Ramos Núñez, Ius commune, on La Recoleta in Arequipa. His research explores the 16th and $17^{\text {th }}$ books of that repository. With respect to private libraries, one of the most prominent in $17^{\text {th century Lima }}$ belonged to father Francisco de Avila, a priest associated with the campaign against "indigenous idolatry" in Huarochirí, see Hampe Martínez, Cultura barroca y extirpación de idolatrías. Notable Limeño jurists also held significant book collections in the 17th century; see Novoa, The Protectors of Indians in the Royal Audiencia of Lima, 190-200.

27 On the relevance of Gómez de Silva's Práctica, see Premo, Children of the Father King, 36-37. Gómez de Silva also included in the second part of his book a selection of the Partidas with reference to cases of minors, see Gómez de Silva, Práctica y Instrucción para albaceas, tutores y curadores que administran bienes de menores.

28 Such as Diego Pérez Gallego's Recuerdo para escrivanos de algunas cosas que saben o deven saber en los escritos y contratos, Lima 1649.

29 An important collection of these printed informes en Derecho are stored at the National Library of Peru. They were eloquent examples of the construction of professional legal arguments in the Habsburg Andes. See, for example, Sosa, Informe en Derecho. 
to the Limeño case. ${ }^{30}$ These pleadings contained passages in Latin written by prominent European jurists and theologians, but also included numerus sources of law in the argumentation. ${ }^{31}$ Influential and wealthy clients, like nobles, traders, mine owners, and religious orders financially supported these prints. Around 1625, Juan Enríquez de Borja, Marquis of Santiago de Oropesa (and on behalf of his wife Ana María Lorenza García Sayri Tupac de Loyola) hired four prominent advocates of the Audiencia of Lima to write and sign in a printed allegation in his case before the Limeño court. ${ }^{32}$ In 1631 , mine owners from Potosí took the services of Licentiate Sebastián de Sandoval y Guzmán, a Limeño advocate, to claim the reduction of their tributary duties and the recognition of privileges in the Council of the Indies. Sandoval prolifically cited jurists and passages of their writings to support his arguments. ${ }^{33}$ His allegation was virtually a memorial, an extended narrative of the main points of their clients.

Publishing works of law was an important factor for the social construction of the colonial legal culture. Moreover, everyday juridical practice transformed

30 Mayagoitia, "Notas sobre los alegatos impresos novohispanos" and Corona González, "Alegaciones e informaciones en Derecho (porcones) en la Castilla del Antiguo Régimen". A list of these porcones (allegations of the advocates and legal reports) from the National Library of Spain can be found in García Cubero, Las alegaciones en Derecho (Porcones) de la Biblioteca Nacional.

31 Barreto, "Legal Culture and Argumentation in the Vice-Reign of Peru from the 16th to the 18th Centuries" offers a rich discussion on the construction of legal arguments in the early 17 th century Peruvian legal literature. On the art of writing in 18th century litigation, see Premo, "Legal Writing, Civil Litigation, and Agents in the 18th-Century Spanish Imperial World". A discussion of the professional roles on the making in trial argumentation, in Tormo Camallonga, "El abogado en el proceso y la argumentación en los informes jurídicos del s. XVIII".

32 Ana María Lorenza, Marchioness of Santiago de Oropesa, was the great-granddaughter of Sayri Tupac (c. 1535-1561), Inca ruler in Vilcabamba and son of Manco Inca (r. 15361544). The marquises were involved in numerous lawsuits in the Limeño court and the Council of the Indies. Their cases illustrate how litigation was also an important activity of the nobility in the Andean Habsburg, see BNP B 1081, 1614 (barcode: 2000001501). In their allegation, the letrados who signed the piece were Dr. Leandro de la Reinaga Salazar, Licentiate Lorenzo Pardo del Castillo, Dr. Francisco Ramos Galván (one of the best lawyers of early $17^{\text {th }}$ century Lima and law professor), and Dr. Diego Messia de Zúñiga. Marquis of Oropesa counted on the services of the best Limeño advocates in the early 17 th century. On his allegation, see Oropesa, Por el Maqués de Oropesa.

33 Sandoval y Guzmán, Pretensiones de la Villa Imperial de Potosí, first argument. His text is not paged. Sandoval was an advocate in the Audiencia of Lima, representative of the Potosino mineowners and their petitioner in the Council of the Indies. His memorial was published in Madrid in 1634. He travelled to the metropolitan capital city to expose the views of his clients and also claim for a judicial position in the Spanish American Audiencias. 
the Andean legal landscape. Courts, notary offices, and the local scenarios of customary justice were the rooms in which those changes took place. In this context, practitioners and clientele rethought the normative order insofar as they provided new meanings of western legal categories.

Legal manuals provided guidelines for the daily work of experts. In litigation, prácticas covered different topics such as the types of procedures, stages of a trial, evidence, and the templates for the writing of pleas. This legal literature also prescribed the abilities and required duties of scribes and procurators. In some respects, it delineated the features of a good facilitator. In mid-16th century, Gabriel de Monterroso argued that good writing and diligence were main scribal qualities. ${ }^{34}$ In the early 17 th century, Juan Muñoz, another pragmatic author, enumerated the expected qualities of a good procurator in his Práctica de procuradores (1618). Muñoz, who was himself a procurator in Huesca (north-eastern Spain), wrote the foregoing based on his own professional experience. ${ }^{35}$ In theory, and in Castilian law, procurators were subordinate to lawyers. In practice, nonetheless, they were the real agents in litigation. They represented their clients before the lower and higher courts and were aware of the state of their cases. Given that personal proximity, procurators gained a plethora of information from litigants driving their cases. It determined that they should follow ethical rules, professional secrecy being one of their most relevant duties.

In Spanish America, two important procedural manuals circulated in the early 17th century: Curia Philipica (of 1603) and Instrucción para litigantes (of 1612). Juan de Hevia Bolaño, himself a facilitator, dedicated a couple of pages to enumerate the function and duties of advocates and procurators using as its main source the Siete Partidas. Afterwards, Hevia detailed the steps and logic of the "ordinary procedure", the model for all procedures in civil and canonical litigation. However, the information on pleas, claims, counterclaims, notifications, times for the submission of pleas, and appeals was common for all procedures. ${ }^{36}$ Alonso de Villadiego, for his part, worked as an advocate in Madrid and also as a corregidor; he was the author of several books on Castilian law. His Instrucción, the first edition of which was printed in 1612, was an important

\footnotetext{
34 Monterroso y Alvarado, Práctica civil y criminal e instrucción de escribanos, fol. 7r.

35 Muñoz, Práctica de procuradores, fols. 1r and $14 \mathrm{r}$.

36 Hevia Bolaños, Curia Philipica, primero y segundo tomo, vol. 2, 1-176.
} 
manual in which the stages of the trial in the ordinary way (vía ordinaria) was described in its first part. ${ }^{37}$

Legal history is also an intersection between intellectual and social history. ${ }^{38}$ Law has specific categories that actors and agents use to defend, preserve, or increase their rights. Although specialists were central in the knowledge of law, ordinary litigants had also their own ideas of rights and justice. The three following examples try to illustrate the uses of law by king's subjects and their notions of liberty, good government, and local justice. ${ }^{39}$ They appropriated these concepts incorporating them into their legal experience and providing new meanings. This was a process of construction of legal discourses in early colonial Peru. In February 1561, Domyngo "natural de la cibdad de Goa de la Yndia de Portugal", presented himself in the Audiencia of Lima. He claimed to be recognised legally as a free person. Domingo indicated that he had been born in Goa, in southern India. At that time, Goa was an important port city of the Portuguese in the Estado da India. Goa was a central place in the circulation of people, objects, and in the transatlantic trade from Asia to Africa (and then to America). Domingo's advocate, Licentiate Diego de Pineda, also emphasised his condition of "poor" and miserabilis, two elements of the legal status of Amerindians.$^{40} \mathrm{He}$ claimed to be treated under that legal category. It meant in judicial terms to receive specialised legal advice by a lawyer of the Audiencia (private or an officer) and that the case should be under the exclusive jurisdiction of that Limeño tribunal. Domingo's petition also indicated that don Francisco Pérez Lezcano, a leading citizen in Trujillo treated him erroneously as "a slave" and tried to sell him. ${ }^{41}$

37 Villadiego, Instrucción politica y practica judicial, 1-28.

38 For recent debates on methodologies in legal history and the recovery of popular voices, see Musson and Stebbings (eds.), Making Legal History and Humfress, Orthodoxy and the Courts in Late Antiquity.

39 New Andeanist legal history focuses on the usage of law by subaltern and ordinary litigants, see Dueñas, "Introduction", 4-14. Two important examples in this direction are McKinley, Fractional Freedoms and Premo, The Enlightenment on Trial.

40 AGN-RA, Causas Civiles, leg. 6, cuad. 34, 1561, fol. 1r, Lima, February 27, 1561. Licentiate Diego de Pineda was at that time also prosecutor in the Audiencia. He had been a private lawyer and consultant of the council of Lima. In the decade of the $155^{\circ}$ he was also Corregidor of the city of Trujillo. Given that circumstance, he met Francisco Pérez Lezcano, encomendero in the valley.

41 On Pérez Lezcano he said "se sirve de my como esclavo y a enbiado a mandar al secretario Fran[cis]co de Carvajal como tal esclavo me venda en ella [in Trujillo] siendo como es contra Dro. de vno y yo reclamo libertad por ser como soy libre y no sujeto a cautiberio ninguno", AGN-RA, Causas Civiles, leg. 6, cuad. 34, 1561, fol. 1r. 
His petition was contradicted by the legal facilitators ${ }^{42}$ of Francisco Pérez Lezcano. His advocate, Licentiate Jerónimo López Guarnido indicated in the counterclaim that Domingo had not been born in the "Yndia de Portugal". Instead, Domingo was "subject of serfdom" having been purchased as a slave. ${ }^{43}$ Also, López Guarnido denied the quality of legal party of Domingo in the trial, an example of the use of procedural technicalities in the Limeño cases. The legal document of sale, presented by Pérez Lezcano, called Domingo a "negro" being the skin colour an element to emphasise his status as a slave. In that sale contract, Alonso de Escobedo sold Domingo as a slave for 425 pesos in October 1558. In this document, Domingo was defined also as troublemaker and ladino having a mark on his face. ${ }^{44} \mathrm{He}$ was sold due to his improper behaviour.

The ideas of liberty and free personal status were central in Domingo's argumentation. They were also part of a transatlantic rhetoric in a time of debate about the Amerindian rights. Between 1530 and 1550, Amerindian litigants in the Council of the Indies demanded their judicial recognition as free individuals. ${ }^{45}$ The struggles for liberty were part of a legal mobilisation (and circulation of ideas and doctrines) on both sides of the Atlantic. Domingo's case also shows how the ideas of ethnicity and legal status mingled. In several pleadings, he emphasised his relationship with the city of Goa and the Portuguese Atlantic world.

Domingo's strategy aimed at pointing out that he had been free since his birth. Most of his six witnesses were members of the nascent Portuguese Atlantic community in Lima. ${ }^{46}$ They exemplified the presence of diasporic communities in the Peruvian capital.

42 His advocate was Licentiate Jerónimo López Guarnido and his procurator (procedural expert) was Francisco de la Torre (fol. 6r).

43 AGN-RA, Causas Civiles, leg. 6, cuad. 34, 1561, fol. 2r-v, Lima, April 21, 1561. "Y lo otro por q el dicho Domyngo no es de la dicha Yndia de Portugal ni libre, antes es esclavo subjeto a la dha. Servidumbre e como tal le con[pró] mi pte". (fol. 2v).

"Un esclavo llamado Domyngo, ladino, de hedad de veynte y siete años poco mas o menos, que tiene un letrero en el rostro que dize Bartolomé Garrido, e lo bendo por ladrón, borracho, huydor e jugador y con las demas tachas", AGN-RA, Causas Civiles, leg. 6, cuad. 34, 1561 , fol. $37 v$ v. On the question of skin color: "qual dho. Alonso Descobedo my padre ha e tiene contra las personas de quien obo el dho. negro [...] e defender, e hazer cierto e sano e seguro de paz el dho negro" (vid. fol. 38v). The entire document in fols. $37 \mathrm{v}-39 \mathrm{r}$.

45 Van Deusen, Global Indios, 125-146.

46 The declarants were Pedro Diaz (from Algarve), Antón de Cordova (from "Yndia de Portugal”), Jorge Fernandes (from Goa), Manuel Paez (from Trujillo in Peru), Simón de Cáceres (from Goa and "mulatto"), and Manuel de Ribero ("Yndio natural de Goa"), see

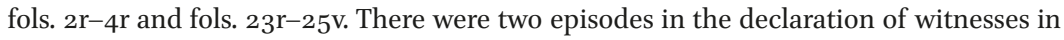
March and November of 1561 . 
Pedro Diaz from Algarve indicated that at least twenty years ago (around the decade of 1540) he was in "la Isla Tercera" and saw how a ship struck a rock and wrecked. He went to help and rescued Don Cristóbal and Domingo, his servant. That ship came from the "Yndia of Portugal" and Domingo was a free servant. Diaz underlined that all inhabitants from "la dicha Yndia" are free people. He also added that Domingo was "poor and miserable". ${ }^{47}$ Jorge Fernandes, "of mulatto skin colour", argued that he knew Domingo at least for one year and said that all Indians of the "land of the Prince Juan" had been free. Manuel Paez, another witness, declared that Domingo was from Goa and that people of that community were free. His witnesses asserted that he had been born free, his parents were from Goa, he had embarked to the New World, and that he was a good person. In addition, they backed Domingo's version about his Goan origin, providing the name of his parents and his belonging to the local community. They said that Domingo spoke the local language of Goa. With this information, Domingo's defence insisted on his local origin, his status as a free person, and the idea that he was the result of an error in persona. The central position is that his status was erroneously denied to him and that he was considered being a slave by his owner.

Domingo's case was not the only early case of liberty in the Audiencia. Indeed, historical evidence shows that other cases occurred previously. In 1548, in the time of the Civil War between Pizarrist factions, Francisco, an "Indian of Tenochtitlán" demanded to be recognised legally as a free person. ${ }^{48}$ Liberty as a synonym of human dignity was employed as argument in the courts. The central point is that they were born free and erroneously considered slaves despite their status. Francisco used also an argument of natural law, an important ingredient of the legal argumentation in Peruvian colonial courts. Francisco's case exemplifies the relevance and circulation of legal ideas of natural and human dignity. In turn, his owner, Juan de Salamanca, artisan, considered that he was a slave and had a mark on his face. ${ }^{49}$ Facial brands signaled the status of certain individuals in the 16 th century.

"Good government" was another important political concept in early modern Castile. Of medieval origin, this principle had diverse meanings and political implications. One of them was the "fair" justice administration at local

47 His declaration was given on 26 February, 1561 . He stated: "Y acudió de los primeros a socorrer el dho navío q se perdió [...] y entre los q[ue] se acuerda q tomó a un caballero q se dezia don Cristóbal e de Domyngo por su criado" (fol. 2r).

48 BNP A-208, 1546 (barcode: 2000000097).

49 "Lo otro dixo q lo de Franco [Francisco] yndio esclavo y te [tiene] en el rostro el hierro del rey", fol. 12 r. 
level. In colonial times, the juicio de residencia (a trial after the ending of an authority's tenure) was the opportunity in which the subjects could denounce abuses and misadministration exercised by the authorities. In the trial of the local authorities of Santa (a small Spanish town in coastal central Peru), subjects, like Juan Díaz Melecio, accused the alcalde (the magistrate of the city) Juan de Mata of having denied litigants their access to justice. The alcalde had avoided to investigate the criminal accusations of some local residents. Juan Díaz Melecio, "vecino de la dicha villa", gave his testimony, and his words are a privileged vehicle to know his ideas of justice. He told how the alcalde cultivated favouritism and rejected to investigate the case of Juan Carrasco's wife. She had requested the intervention of the alcalde to order the payment of a debt by Diego de Elena Herrero, who was a close friend of the alcalde. Díaz Melercio also enumerated other offenses of the alcalde. He narrated his numerous incidents with the aldermen and also his lack of interest to maintain the social morality in the town. Thus, Díaz Melecio pointed out that the alcalde had tolerated the amancebamiento (cohabitation) of many couples and permitted gambling and card games without punishing all "public sins". ${ }^{50}$ During colonial times, the denial and obstruction of justice was considered corruptela, an antecedent of what we know today as legal corruption. ${ }^{51}$

Viceroy Francisco de Toledo (r. 1569-1581) reorganised the Andean space relocating the native population in small towns called reducciones. ${ }^{52}$ The political model utilised was the medieval Castilian municipality made up of alcaldes as magistrates (judges and mayors), aldermen, and scribes. ${ }^{53}$ In San Damián de Urotambo (in Huarochirí, in Lima's highlands), alcaldes solved disputes and scribes recorded them in files. In 1631, in a lawsuit for land, the litigating parties invoked Castilian property law when submitting their suits and pleadings in Spanish. ${ }^{54}$ The parties (and probably their legal experts) used all procedural technicalities that were common in litigation in the high courts of justices like the Audiencia of Lima. A written procedure, with specific procedural stages, and recorded in a file, were some of the facets of this dispute. The alcalde was don Carlos Marcelo Canchaguaman, a member of the local nobility, and his

5O AGN-JR, leg. 1, cuad. 1, fols. 21v-22v.

51 Rosenmüller, "Introduction", 3-7.

$5^{2}$ Mumford, Vertical Empire.

53 Moore, The Cabildo in Peru under the Hapsburgs, 3-30.

54 BNP B 1483, 1637 (barcode: 2000001898), fol. 2r, April 1637. I thank José Carlos de la Puente Luna for this reference. This file is an important testimony on local justice in the colonial Peruvian countryside, and it is one of the few documents that are still stored in national archives. Unlike in Mesoamerican towns, there are few remaining written dossiers of rural litigation in the Habsburg Andes. 
scribe was his father, don Cristóbal Choquecasa, ${ }^{55}$ lord and local aristocrat. Don Cristóbal was bilingual, a go-between, fluent in Spanish, and most likely the best informant of Father Francisco de Avila. ${ }^{56}$ The latter was the parish priest and a prominent extirpator of idolatry who collected the oral narratives of the local religion in Huarochirí. Don Cristobal Choquecasa's familiarity with Castilian legal institutions illustrates the reutilisation of this legal order in the countryside and its powerful influence over local affairs.

Don Cristóbal Choquesaca's case is especially relevant for observing the transformation and the circulation of legal practices in the Andes. As mentioned, he was especially trained in law. He demonstrated the uses of legal formalism and was familiar with legal practice. He was not only a user of justice - as a litigant - but also a legal expert despite the fact that practicing the legal profession was exclusively in the hands of Europeans. His use of a legal vernacular language shows how the normative experience of Castile, as expressed in the "leyes de estilo", became an important parameter in the resolution of disputes. The comparison of language and the presence of experts sheds light on the participation of a rural community of legal experts in litigation - and in a justice of "sticks and branches", as Yanna Yannakakis and Bianca Premo have called it. ${ }^{57} \mathrm{~A}$ generation of indigenous legal experts emerged from that everyday legal practice in rural and urban areas..$^{58}$

The enormous corpus of treatises, manuals, and moral and legal literature that circulated in colonial Peru were important components in the construction of the local legal culture. This concept refers to the general understanding of law (or laws) as well as its social usage. Although some doctrines were dominant in the official scenario (the idea of "two republics", the notions of miserabilis/ neophyte, and the assumption of a good, benevolent, and fair king), it is also relevant to explore how these and other conceptions were socially assimilated (or "translated") and adapted to local needs. In the classic historiography on books, the main emphasis is on the "collection" (or accumulation) itself

55 On Don Cristóbal Choquecasa's abilities, usage of Castilian law, and his role as legal expert, see the study of Puente Luna, "Choquecasa va a la Audiencia".

56 Or even the author, see Durston, "Cristóbal Choquecasa and the Making of the Huarochirí Manuscript" and Puente Luna, "Choquecasa va a la Audiencia".

57 Premo and Yannakakis, "A Court of Sticks and Branches", 29-31, 33-35.

58 Dueñas, "The Lima Indian Letrados". 
rather than on the process of circulation of the ideas that these printed materials contained. Over the last years, historiography interrogates the forms and ways in which ordinary legal users created their own normative imaginaries in a context of aristocratic and traditional social order regimes. A magisterial work by E.P. Thompson, Customs in Common, offers a pathway to observe how subaltern people crafted their legal regimes despite the pressures of landlords, monarchies, and local elites. ${ }^{59}$ Thus, ordinary subjects developed their juridical thought from the ground up by using their social experience and notions of law.

A normative order conceived in the European experience was exported to the New World. The diversity of peoples in the Andes (indigenous, Europeans, mestizos, Africans, and Asians) was a feature of that society, and it multiplied the perspectives on law. Members of these collective groups selected legal resources and used the courts or other scenarios for their own agendas. Andean people gained the reputation of being litigious since the mid-16th century appropriating the court scenario and technicalities as a space to contest colonialism. Likewise, the peoples of African descent used canon law tribunals with vitality, creativity, and audacity, as Michelle McKinley has demonstrated. The regulations and tribunals of the Catholic Church opened up some avenues for the Afro-Peruvians since the mid-16th century (and mainly in the 17th) to demand their liberty or a just treatment. ${ }^{60}$ Both Andeans and Africans brought their demands before civil and canon law tribunals, and made their voices heard in these courts.

The circulation of ideas generated a local legal culture which, although connected with the European origins, was modelled on the American soil. This development should not be conceived as a transplant but as a process of transformation and creation. In the courtrooms, lawyers and litigants were central, but also in other episodes of legal practices. There are several examples of such a circulation of ideas and they not only refer to male actors and litigants but even include women as well. Female litigants were also main actors in the construction of a transatlantic legal culture. It was transatlantic because the elements of the European discourse were appropriated and developed by the subjects in the Andean territories. They added their own voices in an ancien regime context. A gigantic universe of printed materials circulated in the Andes since the early period of the Spanish colonisation. The conquistadores were accompanied by books and printed material. However, this rich intellectual world was appropriated and translated by several agents in Habsburg Peru. Professionals (advocates, procurators, scribes, solicitors, and paralegals) were

59 Thompson, Customs in Common.

6o McKinley, Fractional Freedoms. 
key in that process. At the same time, however, it was the decision and initiative of the king's subjects because they mobilised that legal order. As recent historiography on law and empire shows, the vast and long-lasting empires relied on the active participation of their subjects. ${ }^{61}$ They were the backbone of imperial political edifices. In the Andes, the Castilian tradition in administration, Catholic faith, and legal order transformed king's vassals, but they also transformed the language and the ideas of the empire.

The consequence of that process was the enrichment of Castilian law and its use in the own experience of locals. This process also influenced legal rhetoric. So, gradually, a particular discourse and a characteristic practice of law developed in the American colonies.

Since the early period of colonisation, printed books and manuals circulated in the Andes. There were two significant phases in this process: (a) The period of import of European production between 1535 and 1584 and (b) the gradual importance of the locally printed materials since 1584. In 1584, Antonio Ricardo opened his printing workshop in Lima. The first book produced in the Ricardian laboratory was a religious one but law increasingly acquired importance. The 17th century was the time of the Golden Age of Limeño local production due to the enthusiastic participation of Creole authors. They wrote memorials, allegations, sermons, manuals, and a diversity of legal materials. Theology played a crucial function since it oriented the moral discourses, which were clearly expressed in preaching and local sermons. This vibrant process of intellectual creativity should also be related to the social practice of law, and the construction of a local legal culture. Evidence shows how the king's subaltern subjects used the lexicon, vocabulary, and legal liturgy of the colonists for their own ends.

The courtroom was a laboratory to test the circulation of legal ideas. Litigation involved several actors in higher and lower courts. These forums allow us to perceive the legal ideas that circulated there, and some were born from below. The colonial subjects created and expanded their own ideas in topics such as liberty rights. A local class of facilitators emerged in the colonial context. In San Damián de Huarochirí, these facilitators made law and used the Castilian legal system.

Pragmatic legal literature and the circulation of ideas were central components in the making of colonial Peru. Procedural activity and the use of courts

61 Duindam, Harries, Humfress and Hurvitz (eds.), Law and Empire. 
opened an important scenario. In particular, texts written by Hevia and Villadiego circulated in the colonial world. They were manuals and simultaneously texts about the duties of facilitators. Likewise, however, the litigants and legal users employed that channel and developed their own narratives. This type of literature and the atmosphere of the period generated a legal culture that endured for a long time.

\section{Acknowledgements}

My thanks to Otto Danwerth, Agnes Gehbald, and Pilar Mejía for their comments, bibliographic suggestions, and critical reading of this essay.

\section{Bibliography}

\section{Manuscripts}

Archivo General de la Nación, Lima (AGN-JR) (Juicios de residencia), leg. 1, cuad. 1. Archivo General de la Nación, Lima (AGN-RA) (Real Audiencia), Causas Civiles, leg. 6, cuad. 34,1561 .

Biblioteca Nacional del Perú, Lima (BNP), A-208, 1546 (barcode: 200ooooo97).

BNP, B 1081, 1614 (barcode: 2000001501).

BNP, B 1483, 1637 (barcode: 2000001898).

\section{Printed Sources}

Agia, Miguel de, Tratado que contiene tres pareceres graves en Derecho, que ha compuesto el Padre Fray Miguel Agia de la Orden del Señor San Francisco [...], Lima 1604: Antonio Ricardo.

Alvarez, Bartolomé, De las costumbres y conversión de los indios del Perú. Memorial a Felipe II, Madrid [1587-1588] 1998.

[Anon.,] Descripción de la Villa y minas de Potosí, in Relaciones geográficas de IndiasPerú, Madrid [1603] 1965, 372-385.

Libros de cabildos de Lima. Libro primero (años 1534-1539), ed. Lee, Bertram, Lima 1935. Gómez de Silva, Domingo, Práctica y Instrucción para albaceas, tutores y curadores que administran bienes de menores, Lima 1640: Pedro Cabrera.

Hevia Bolaños, Juan de, Curia Philipica, primero y segundo tomo, 2 vols., Madrid [1797] 1989 .

Monterroso y Alvarado, Gabriel de, Práctica civil y criminal e instrucción de escribanos, Valladolid 1563: Francisco Fernández de Córdoba, Impresor de la Majestad Real. Montesinos, Fernando de, Anales del Perú, 2 vols., Lima [1642] 1906. 
Muñoz, Juan, Práctica de procuradores para seguir pleitos civiles, y criminales, hecha y ordenada por Juan Muñoz, procurador de causas en la ciudad de Guesca. Añadiday enmendada en esta impression, y con nuevas adiciones, conforme a la Nueva Recopilación, Madrid 1618: Diego Flamenco, a costa de Manuel Rodríguez, librero.

Ondegardo, Polo, Informe del licenciado Polo Ondegardo al licenciado Briviesca de Muñatones [...], in Pensamiento colonial crítico. Textos y actos de Polo Ondegardo, ed. Lamana, Gonzalo, Lima [1561] 2012, 139-204.

Oropesa, Marquis of Santiago de, Por el Maqués de Oropesa como marido de doña María de Loyola Coya sobre la satisfacción que pretende le haga Su Majestad por los derechos y pretensiones en que viene informado por la Real Audiencia de Lima, Lima ca. 1625.

Pérez Gallego, Diego, Recuerdo para escrivanos de algunas cosas que saben o deven saber en las escrituras y contratos. Lima 1649: Jorge López de Herrera.

Sandoval y Guzmán, Sebastián de, Pretensiones de la Villa Imperial de Potosí, propuestas en el Real Consejo de las Indias, Madrid 1634: Por la viuda de Juan Gonzalez.

Sosa, Francisco de, Informe en Derecho cerca de la validación del testamento del capitán Andrés Cintero, que murió en la Villa de Potosí, Lima 1648.

Vadillo, Bartolomé, Sermón en el quarto miércoles de quaresma [...] Se intima a los señores juezes y abogados la obligación de su oficio, las causas en las que pueden pecar conforme los sumistas, Lima 1648: Pedro Cabrera.

Villadiego, Alonso de, Instrucción politica y practica judicial [...], Madrid [1612] 1766: Antonio Marin.

\section{Literature}

Alaparrine-Bouyer, Monique, "La biblioteca del Colegio de Yngas nobles: San Borja del Cuzco", in Histórica 29:2 (2005), 163-179.

Alaparrine-Bouyer, Monique, La educación de las élites indígenas en el Perú colonial, Lima 2007.

Alonso Romero, M. Paz, “Theoria y Praxis en la enseñanza del Derecho: Tratados y prácticas procesales en la Universidad de Salamanca a mediados del siglo XVI", in Anuario de Historia del Derecho Español 6o (1991), 451-547.

Barreto, Herman, "Legal Culture and Argumentation in the Vice-Reign of Peru from the 16th to the 18th Centuries", in Clio and Themis 2 (2009) (http://www.cliothemis. com/Legal-Culture-and-Argumentation-in).

Brundage, James A., Medieval Canon Law, London 1995.

Charles, John, “'More Ladino than Necessary': Indigenous Litigants and the Language Policy debate in Mid-Colonial Peru", in Colonial Latin American Review 16:1 (2007), 23-47.

Corona González, Santos M., "Alegaciones e informaciones en Derecho (porcones) en la Castilla del Antiguo Régimen", in Anuario de Historia del Derecho Español 73 (2003), 165-192. 
Danwerth, Otto, "La circulación de literatura normativa pragmática en Hispanoamérica (siglos XVI-XVII)", in Duve, Thomas (ed.), Actas del XIX Congreso del Instituto Internacional de Historia del Derecho Indiano, Berlín 2016, vol. 1, Madrid 2017, 359-40o.

Dueñas, Alcira, "Introduction: Andeans Articulating Colonial Worlds", in The Americas 72:1 (2015), 3-17.

Dueñas, Alcira, "The Lima Indian Letrados: Remaking the República de Indios in the Bourbon Andes", in The Americas 72:1 (2015), 55-75.

Duindam, Jeroen, Jill Harries, Caroline Humfress and Nimrod Hurvitz (eds.), Law and Empire. Ideas, Practices, Actors, Leiden 2013.

Durston, Alan, "Cristóbal Choquecasa and the Making of the Huarochirí Manuscript", in Ramos, Gabriela and Yanna Yannakakis (eds.), Indigenous Intellectuals. Knowledge, Power, and Colonial Culture in Mexico and the Andes, Durham 2014, 151-169.

Fox, K.V., "Pedro Muñiz, Dean of Lima and the Indian Labor Question", in The Hispanic American Historical Review 42:1 (1962), 63-88.

García Cubero, Luis, Las alegaciones en Derecho (Porcones) de la Biblioteca Nacional, Madrid 2004.

Hampe Martínez, Teodoro, Cultura barroca y extirpación de idolatrías: La biblioteca de Francisco de Avila (1648), Cusco 1996.

Harrison, Regina, Sin and Confession in Colonial Peru: Spanish-Quechua Penitential Texts, 1560-1650, Austin, TX 2015.

Härter, Karl, "The Early Modern Holy Roman Empire of the German Nation (14951806): A Multi-Layered Legal System", in Duindam, Jeroen, Jill Harries, Caroline Humfress and Nimrod Hurvitz (eds.), Law and Empire. Ideas, Practices, Actors, Leiden 2013, 111-131.

Humfress, Caroline, Orthodoxy and the Courts in Late Antiquity, Oxford 2007.

Leonard, Irving, "On the Lima Book Trade, 1591", in The Hispanic American Historical Review 33:4 (1953), 511-525.

Mayagoitia, Alejandro, "Notas sobre los alegatos impresos novohispanos", in Universidad Nacional Autónoma de México (ed.), Memoria del IX Congreso del Instituto Internacional de Historia del Derecho Indiano, México 1995, 1001-1029.

McKinley, Michelle, Fractional Freedoms: Slavery, Intimacy, and Legal Mobilization in Colonial Lima, 160o-170o, Cambridge 2016.

Monsalve, Martín, "Del estudio del Rosario a la Real y Pontificia Universidad Mayor de San Marcos", in Histórica 22:1 (1998), 53-79.

Moore, John Preston, The Cabildo in Peru under the Hapsburgs. A Study in the Origins and Powers of the Town Council in the Viceroyalty of Peru 1530-1700, Durham 1954.

Mumford, Jeremy R., Vertical Empire. The General Resettlement of Indians in the Colonial Andes, Durham 2012.

Musson, Anthony and Chantal Stebbings (eds.), Making Legal History: Approaches and Methodologies, Cambridge 2012. 
Novoa, Mauricio, The Protectors of Indians in the Royal Audiencia of Lima. History, Careers and Legal Culture, 1575-1775, Leiden 2016.

Palau y Ducet, Antonio, Manual del librero hispanoamericano, vol. 10, Barcelona 1957.

Premo, Bianca, Children of the Father King: Youth, Authority, and Legal Minority in Colonial Lima, Chapel Hill, NC 2005.

Premo, Bianca, The Enlightenment on Trial: Ordinary Litigants and Colonialism in Spanish America, Oxford 2017.

Premo, Bianca, "Legal Writing, Civil Litigation, and Agents in the 18th-Century Spanish Imperial World", in Beezley, William H. (ed.), Oxford Research Encyclopedia of Latin American History (online publication) 2017 (10.1093/acrefore/ 9780199366439.013.247).

Premo, Bianca and Yanna Yannakakis, "A Court of Sticks and Branches: Indian Jurisdiction in Colonial Mexico and Beyond", in The American Historical Review 24:1 (2019), 28-55.

Puente Luna, José Carlos de la, Los curacas hechiceros. Batallas mágicas y legales en el Perú colonial, Lima 2007.

Puente Luna, José Carlos de la, "Choquecasa va a la Audiencia: Cronistas, litigantes y el debate sobre la autoría del Manuscrito quechua de Huarochirí", in Histórica 39:1 (2015), 139-158.

Puente Luna, José Carlos de la, Andean Cosmopolitans: Seeking Justice and Reward at the Spanish Royal Court, Austin, TX 2018.

Ramos, Gabriela, "Indigenous Intellectuals in Andean Colonial Cities", in Ramos, Gabriela and Yanna Yannakakis (eds.), Indigenous Intellectuals. Knowledge, Power, and Colonial Culture in Mexico and the Andes, Durham 2014, 21-38.

Ramos Núñez, Carlos, Ius commune. Libros y juristas en la Biblioteca de La Recoleta. Siglos XVIy XVII, Arequipa 2016.

Rosenmüller, Christoph, "Introduction: Corruption, Abuse, and Justice in the Iberian Empires", in Rosenmüller, Christoph (ed.), Corruption in the Iberian Empires. Greed, Custom, and Colonial Networks, Albuquerque, NM 2017, 1-12.

Temple, Ella D., "El jurista indiano don Gaspar de Escalona y Agüero, graduado en la Universidad de San Marcos", in Documenta, vol. II (1949), 545-586.

Thompson, Edward P., Customs in Common, New York 1991.

Tormo Camallonga, Carlos, "El abogado en el proceso y la argumentación en los informes jurídicos del s. XVIII", in Ivs Fvguit 10-11 (2001-2002), 1079-1131.

Van Deusen, Nancy, Global Indios. The Indigenous Struggle for Justice in SixteenthCentury Spain, Durham 2015.

Wilkinson, Alexander S., "Ensayo introductorio. La publicación en la Península Ibérica a principios del Siglo de Oro, 1472-16oo", in Wilkinson, Alexander S. (ed.), Libros Ibéricos. Libros publicados en español o portugués o en la Península Ibérica antes de 1601, Leiden 2010, XXXIII-XLVI. 